\title{
Growth, yield and gas exchanges of 'D’Angola' plantain under different plant densities
}

\author{
Vagner A. Rodrigues Filho' ${ }^{1}$, Sérgio L. R. Donato ${ }^{2}$, Alessandro M. Arantes ${ }^{2}$, Mauricio A. Coelho Filho ${ }^{3} \&$ \\ Marcelo B. Lima ${ }^{3}$ \\ ${ }^{1}$ Sítio Barreiras Fruticultura Ltda./Setor Técnico, Missão Velha, CE, Brasil. E-mail: vagner@sitiobarreiras.com.br (Corresponding author) - ORCID: \\ 0000-0001-7702-7445 \\ ${ }^{2}$ Instituto Federal de Educação, Ciência e Tecnologia Baiano/Setor de Agricultura, Guanambi, BA, Brasil. E-mail: sergio.donato@ifbaiano.edu.br - \\ ORCID: 0000-0002-7719-4662; alessandro.arantes@ifbaiano.edu.br - ORCID: 0000-0002-7520-9891 \\ ${ }_{3}^{3}$ Embrapa Mandioca e Fruticultura, Cruz das Almas, BA, Brasil. E-mail: mauricio-antonio.coelho@embrapa.br - ORCID: 0000-0002-4667-5535; \\ marcelo.lima@embrapa.br - ORCID: 0000-0002-9073-7246
}

\begin{abstract}
Information about production, crop systems and economic viability for technical grown of plantain are scarce in Brazil. Few technologies developed specifically for plantain are available; thus, there are many adaptations of information on banana crops extrapolated to plantain. The objective of this study was to evaluate the growth, nutritional status, gas exchanges, water use efficiency and yield of 'D'Angola' plantain under different plant densities, in the first production cycle. The treatments consisted of six plant densities $\left(1,111 ; 2,500 ; 2,777 ; 3,125 ; 3,571\right.$; and 4,166 plants $\left.\mathrm{ha}^{-1}\right)$, which were evaluated in a randomized block design with four repetitions. Vegetative growth, leaf nutrient concentrations at the flowering stage, gas exchanges (monthly) at two reading times, fruit yield and water use efficiency at harvest were evaluated. The nutritional status is not dependent on plant density. The vegetative growth varied, regardless of the plant density, whereas the leaf area index increased as the plant density was increased. The leaf temperature increased as the plant density was increased. The water use efficiency for fruit yield, as a function of plant density, fitted to a quadratic model, with the maximum value at 3,301 plants ha ${ }^{-1}$. The use of 3,333 plants ha ${ }^{-1}$ is recommended for plantain.
\end{abstract}

Key words: Musa spp., dense planting, leaf area index, photosynthesis, mineral nutrition

\section{Crescimento, produtividade e trocas gasosas de plátano 'D’Angola' sob diferentes densidades de plantio}

RESUMO: No Brasil, são escassas informações acerca dos dados de produção, sobre sistemas de cultivo e viabilidade econômica para exploração tecnificada de plátanos. Há pouca disponibilidade de tecnologias desenvolvidas especificamente para os plátanos, assim, há apenas adaptações de todo o conhecimento gerado para a cultura da bananeira extrapolada aos plátanos. Objetivou-se com o presente estudo avaliar o crescimento, o estado nutricional, as trocas gasosas, a eficiência de uso da água e a produtividade de Plátano 'D'Angola' submetido a diferentes densidades de plantio, no primeiro ciclo de produção. Os tratamentos, seis densidades de plantio: $1.111 ; 2.500 ; 2.777 ; 3.125 ; 3.571 ; 4.166$ plantas $\mathrm{ha}^{-1}$, foram dispostos em um delineamento em blocos casualizados, com quatro repetições. Avaliaram-se: o crescimento vegetativo, os teores de nutrientes nas folhas no florescimento, as trocas gasosas (mensalmente) em dois horários de leitura, os caracteres de rendimento e a eficiência de uso da água na colheita. O estado nutricional independe da densidade de plantio. As características de crescimento vegetativo variaram independentemente das densidades de plantio, enquanto o índice de área foliar aumenta com a densidade de plantio. A temperatura foliar aumenta com o acréscimo da densidade de plantio. A eficiência de uso da água e a produtividade ajustam-se ao modelo quadrático em função da densidade de plantio, sendo o valor máximo com 3.301 plantas ha ${ }^{-1}$. Recomenda-se a utilização prática de 3.333 plantas ha ${ }^{-1}$.

Palavras-chave: Musa spp., plantio adensado, índice de área foliar, fotossíntese, nutrição mineral 


\section{INTRODUCTION}

Information about production, crop systems and economic viability of plantain (Musa spp.) crops are scarce in Brazil. Few technologies developed specifically for plantain are available; thus, there are many adaptations of information on banana crops extrapolated to plantain. Although both the crops can be treated similarly, plantain have different growth habit, size, cycle and genetic. Treating plantain, technically, as banana can lead to inadequate experimental and productive results.

Plantain production in Brazil needs technological solutions, such as determinations of spacings for high-density planting, which allows the expression of the productive potential of cultivars in use by producers, definition of irrigation and fertilization management practices, and mitigation of damages caused by pests and diseases.

According to Rosales et al. (2008), the use of only one production cycle with high plant densities, up to 5,000 plants ha ${ }^{-1}$, has been recommended as a technical management for plantain crops in some great producing countries; and this short crop cycle is due to the vulnerability of these plants to damages in roots and rhizomes caused by nematodes and borers, which naturally limit the crop longevity.

Therefore, increases in plant density may increase fruit yield and water use efficiency for the plantain cultivar D'Angola, without losses in fruit quality. Thus, the objective of this study was to evaluate the growth, nutritional status, gas exchanges, water use efficiency and yield of 'D'Angola' plantain under different densities, in the first production cycle.

\section{Material ANd Methods}

The experiment was conducted from October 2014 to January 2016 in an area of the Instituto Federal Baiano, in

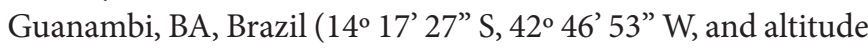
of $537 \mathrm{~m}$ ). The area had a Red Yellow Oxisol, mean texture, hypoxerophytic caatinga vegetation, and plain to slightly wavy relief. The Table 1 presents the chemical attributes of the soil. The mean annual rainfall depth of the region was $680 \mathrm{~mm}$, and the mean annual temperature was $26^{\circ} \mathrm{C}$.

The treatments consisted of six planting densities: 1,111 $(2.0 \times 4.5 \mathrm{~m}), 2,500(2.0 \times 2.0 \mathrm{~m}), 2,777(2.0 \times 1.8 \mathrm{~m}), 3,125$ $(2.0 \times 1.6 \mathrm{~m}), 3,571(2.0 \times 1.4 \mathrm{~m})$, and 4,166 plants ha ${ }^{-1}$ $(2.0 \times 1.2 \mathrm{~m})$, arranged in a randomized block design with four repetitions, totaling 24 experimental plots. Each plot consisted of 20 plants (four rows of five plants), and the six plants of the two central rows were used for the evaluations.

Micro-propagated seedlings from 'D'Angola' plantain plants were used for the planting. Cultural practices were done as recommended for the crop by Rosales et al. (2008). The irrigations were done based on the crop evapotranspiration, considering the reference evapotranspiration (ETo), calculated by the Penman-Monteith method modified by the FAO, using the crop coefficient of 1.4 after the flowering stage, according to Coelho et al. (2012), and a total water depth of 2,546 mm per cycle, complementing the rainfall depth $(602 \mathrm{~mm})$ that occurred during the experiment.

The vegetative growth of the plants was evaluated monthly over the production cycle up to the flowering stage, totaling 10 evaluations, considering: plant height $(\mathrm{PH})$, corresponding to the pseudostem length measured from the base to the apex; pseudostem perimeter at the ground level (PPGL); number of functional leaves in the plant (NLP), corresponding to leaves with at least $50 \%$ preserved area; total leaf area (TLA), considering the width and length of the leaf 3 , according to the expression of Zucoloto et al. (2008) [TLA $=0.5187(\mathrm{~L} \times \mathrm{W} \times \mathrm{N})+$ 9603.5; $\left.\mathrm{R}^{2}=0.89(\mathrm{p} \leq 0.05)\right]$, where $\mathrm{L}$ and $\mathrm{W}$ are, respectively, the length and width of the leaf 3 , and $\mathrm{N}$ is the number of leaves; and the leaf area index (LAI), considering the ratio between total leaf area and area per plant.

The relative growth rates for $\mathrm{PH}\left(\mathrm{PH}_{\mathrm{RGR}}\right)$, $\mathrm{PPGL}\left(\mathrm{PPGL}_{\mathrm{RGR}}\right)$, and TLA (TLA $\left.{ }_{\text {RGR }}\right)$ were determined using Eq. 1.

$$
\mathrm{RGR}=\frac{(\ln \mathrm{P} 2-\ln \mathrm{P} 1)}{\Delta \mathrm{t}}
$$

where:

RGR - relative growth rate for PH, PPGL $\left(\mathrm{cm} \mathrm{cm}^{-1} \mathrm{~d}^{-1}\right)$, or TLA $\left(\mathrm{m}^{2} \mathrm{~m}^{-2} \mathrm{~d}^{-1}\right)$;

P1 - the PH, PPGL $(\mathrm{cm})$, or TLA $\left(\mathrm{m}^{2}\right)$ in the previous evaluation;

P2 - the PH, PPGL $(\mathrm{cm})$, or TLA $\left(\mathrm{m}^{2}\right)$ of the current evaluation; and,

$\Delta t \quad$ - the time between evaluations (days).

The weights of bunches and hands, number of fruits and hands per bunch, fruit weight, and diameter and external length of the fruit were determined after harvest (Santos et al., 2019). The central fruits of the external rows of the second hand were used for the measurements. Fruit yield was determined using Eq. 2 (Robinson \& Galán Saúco, 2012).

$$
\mathrm{FY}=\left(\frac{\mathrm{Pd}}{\mathrm{C}}\right) 12
$$

where:

FY - the fruit yield in $\mathrm{Mg} \mathrm{ha}^{-1} \mathrm{cycle}^{-1}$;

$\mathrm{Pd}$ - the total production in $\mathrm{Mg} \mathrm{ha}^{-1}$; and,

$\mathrm{C}$ - the cycle period in months.

Leaves were sampled at the flowering stage of the first production cycle, according to Rodrigues et al. (2010). Simple leaf samples were collected from each plant in the evaluation

\begin{tabular}{|c|c|c|c|c|c|c|c|c|c|c|c|c|c|c|c|c|c|c|}
\hline Layer & $\mathrm{nH}$ & SOM & P & K & $\mathrm{Ca}$ & $\mathrm{Mg}$ & $\mathrm{H}+\mathrm{Al}$ & CEC & \multirow{2}{*}{$\begin{array}{l}\text { BS } \\
(\%)\end{array}$} & B & Cu & $\mathrm{Fe}$ & $\mathrm{Mn}$ & $\mathrm{Zn}$ & $\mathrm{Na}$ & Sand & Silt & Clay \\
\hline (m) & Pn & $\left(g \mathrm{dm}^{-3}\right)$ & $\left.(\mathrm{mg} \mathrm{dm})^{-3}\right)$ & \multicolumn{5}{|c|}{$\left(\mathrm{cmol}_{\mathrm{c}} \mathrm{dm}^{-3}\right)$} & & \multicolumn{6}{|c|}{$\left(m g d m^{-3}\right)$} & \multicolumn{3}{|c|}{$\left(g_{k g}^{-1}\right)$} \\
\hline $0-0.20$ & 7.9 & 22.0 & 545.1 & 0.9 & 4.7 & 2.4 & 1.1 & 9.2 & 88.0 & 0.9 & 3.3 & 14.0 & 77.2 & 32.4 & 4.6 & 670 & 120 & 210 \\
\hline $0.20-0.40$ & 7.5 & 9.0 & 261.5 & 0.5 & 3.2 & 1.9 & 0.9 & 6.6 & 87.0 & 1.1 & 1.7 & 19.9 & 36.7 & 16.4 & 2.3 & 650 & 170 & 180 \\
\hline
\end{tabular}

Table 1. Chemical attributes of the soil of the experimental area before the planting of 'D'Angola' plantain

SOM - soil organic matter; CEC - cation exchange capacity; BS - base saturation 
area of each replication to form a composite sample. The samples were used to determine the $\mathrm{N}, \mathrm{P}, \mathrm{K}, \mathrm{Ca}, \mathrm{Mg}, \mathrm{S}\left(\mathrm{g} \mathrm{kg}^{-1}\right)$, $\mathrm{B}, \mathrm{Cu}, \mathrm{Fe}, \mathrm{Mn}$, and $\mathrm{Zn}\left(\mathrm{mg} \mathrm{kg}^{-1}\right)$ concentrations.

Gas exchanges were measured monthly in the plants, from the $90^{\text {th }}$ to the $360^{\text {th }}$ day after transplanting (replications), at two reading times $(8: 00 \mathrm{~h}$ and 14:00 h). The leaf 3 or 4 was considered for evaluations, according to its exposition to the Sun, using one plant per experimental unity and five strokes in the reading device after stabilization. A infrared gas analyzer (IRGA; LCPro $^{+}$; ADC BioScientific Ltda) was used to evaluate photosynthesis rate $\left(\mathrm{A} ; \mu \mathrm{mol} \mathrm{CO} \mathrm{CO}^{-2} \mathrm{~s}^{-1}\right)$; transpiration (E; $\mathrm{mmol} \mathrm{H}_{2} \mathrm{O} \mathrm{m}^{-2} \mathrm{~s}^{-1}$ ); stomatal conductance (gs; $\mathrm{mol} \mathrm{m}^{-2} \mathrm{~s}^{-1}$ ); solar radiation on the leaf $\left(\mathrm{Q}_{\text {leaf }} ; \mu \mathrm{mol}\right.$ photons $\left.\mathrm{m}^{-2} \mathrm{~s}^{-1}\right)$; temperature on the leaf $\left(\mathrm{T}_{\text {leaf }} ;{ }^{\circ} \mathrm{C}\right)$; substomatal $\mathrm{CO}_{2}$ concentration $(\mathrm{Ci}$; $\left.\mu \mathrm{mol} \mathrm{CO}_{2} \mathrm{~mol}^{-1}\right)$; instantaneous water use efficiency (A/E); carboxylation efficiency (A/Ci); and photosynthesis quantum or photochemical efficiency $\left(\mathrm{A} / \mathrm{Q}_{\text {leaf }}\right)$.

The water use efficiency was also determined, considering the ratio between bunch and hand weights and total water depth applied to the crop over the production cycle (Coelho et al., 2013).

The statistical analyses of the data of the characteristics evaluated was done considering the following procedures: a) a randomized block design with a $6 \times 10$ split-plot arrangement was adopted for the results of vegetative characteristics, corresponding to six planting densities (plots) and 10 evaluation times (subplots); the data were subjected to analysis of variance, the interactions were evaluated according to their significance, and, then, the data were fitted to regression models or response surface; b) a randomized block design with six treatments (planting densities) was adopted for the results of fruit yield and leaf nutrient contents; the data were subjected to analysis of variance and, when significant, fitted to regression models; c) a randomized block design was adopted, consisting of a $6 \times 2$ factorial arrangement, six planting densities, and two reading times for the physiological characteristics evaluated at the flowering stage; the results were subjected to analysis of variance and the interactions were evaluated according to their significance; the means were compared by the F test and fitted to regression models. In all cases, the fitting to regression models considered the adequacy to the biological phenomenon studied, the $\mathrm{R}^{2}$ value, and the significance of regression coefficients by the $\mathrm{t}$ test.

\section{Results AND Discussion}

The leaf nutrient concentrations of 'D'Angola' plantain in the different planting densities were similar (Table 2). The macronutrient concentrations found were above the sufficiency ranges for plantain (Borges et al., 2016), which are $\left(\mathrm{g} \mathrm{kg}^{-1}\right): 23.3$ 30.8 for N, 1.5-1.9 for P, 21.5-26.6 for K, 0.8-1.9 for S, 4.6-8.3 for $\mathrm{Ca}$, and 3.0-4.2 for $\mathrm{Mg}$.

The micronutrient concentrations found (Table 2) were within the sufficiency ranges for plantain (Borges et al., 2016), except for $\mathrm{Cu}$ and $\mathrm{Fe}$, which were above this range. These ranges are $\left(\mathrm{g} \mathrm{kg}^{-1}\right)$ : 19.8-37.4 for B, 3.8-5.2 for $\mathrm{Cu}, 53.2-92.1$ for $\mathrm{Fe}$, 44.0-428.4 for $\mathrm{Mn}$, and 13.7-19.6 for $\mathrm{Zn}$.

The plant density had no effect on plant height $(\mathrm{PH})$ of the 'D'Angola' plantain evaluated, which increased linearly as a function of days after transplanting (DAT) (Figure 1A). The $\mathrm{PH}$ varied from $20.8 \mathrm{~cm}$ (60 DAT) to $357.97 \mathrm{~cm}$ (341 DAT). The estimated model showed an increase in $\mathrm{PH}$ of $1.08 \mathrm{~cm}$ for each DAT.

Faria et al. (2010) evaluated PH of 'D'Angola' plantain plants at the flowering stage, in the same site, using a plant density of 1,111 plants ha ${ }^{-1}$, and found maximum $\mathrm{PH}$ of $337 \mathrm{~cm}$, which was confirmed by the results found in the present study for the same density. These $\mathrm{PH}$ were higher than those found by Cavalcante et al. (2014) $(279 \mathrm{~cm})$ for the same plant density and phenological stage.

The plant density had no effect on the pseudostem perimeter at the ground level (PPGL) of the 'D'Angola' plantain plants; the means varied, with linear increases as a function of DAT (Figure 1B). The mean PPGL varied from $10.38 \mathrm{~cm}(60$ DAT) to $84.84 \mathrm{~cm}$ (341 DAT). The estimated model showed an increase of $0.2696 \mathrm{~cm}$ in PPGL for each DAT.

Arantes et al. (2010) found positive correlations between PPGL, bunch weight, and hand weight for plantain. Moreover, cultivars with higher PPGL usually have better root system development, and are less susceptible to tipping (Silva et al., 2002) and pseudostem breakage, which are current problems in plantain crops; thus, this is a desirable characteristic when selecting a plant density.

The plant density had no effect on the number of leaves per plant (NLP) (Figure 1C) of the 'D'Angola' plantain plants; the means of the treatments as a function of DAT fitted to a quadratic model, with maximum NLP of 14.90 at 341 DAT.

The NLP at the beginning of flowering stage is related to number of hands per bunch, whereas the NLP at full flowering is related to weights of hands and bunches (Robinson \& Galán Saúco, 2012); at least six functional leaves are required for plantain at flowering stage (Barrera et al., 2009), whereas PrataAnã banana at flowering require 10 to 12 leaves (Rodrigues et al., 2009) and Grande Naine banana require less than 12 leaves (Rodríguez González et al., 2012). Faria et al. (2010) evaluated plantain with spacing of $3.00 \times 3.00 \mathrm{~m}\left(1.111\right.$ plants ha $\left.^{-1}\right)$ and

Table 2. Leaf macro and micronutrient concentrations in 'D'Angola' plantain grown under different plant densities

\begin{tabular}{|c|c|c|c|c|c|c|c|c|c|c|c|}
\hline \multirow{2}{*}{$\begin{array}{l}\text { Planting } \\
\text { density }\end{array}$} & $\mathrm{N}$ & $\mathbf{P}$ & $\mathrm{K}$ & $\mathrm{Ca}$ & $\mathrm{Mg}$ & $S$ & B & $\mathrm{Cu}$ & $\mathrm{Fe}$ & Mn & $\mathrm{Zn}$ \\
\hline & \multicolumn{6}{|c|}{$\left(\mathrm{g} \mathrm{kg}^{-1}\right)$} & \multicolumn{5}{|c|}{$\left(\mathrm{mg} \mathrm{kg}{ }^{-1}\right)$} \\
\hline 1.111 & 33.4 & 2.9 & 36.7 & 10.1 & 6.1 & 2.9 & 24.6 & 9.5 & 123.4 & 73.9 & 22.2 \\
\hline 2.500 & 33.3 & 2.7 & 37.0 & 10.4 & 5.9 & 2.7 & 24.5 & 6.1 & 117.9 & 80.8 & 18.4 \\
\hline 2.777 & 34.0 & 2.8 & 36.3 & 10.7 & 6.4 & 3.0 & 25.3 & 8.7 & 130.1 & 81.5 & 19.6 \\
\hline 3.125 & 35.1 & 2.7 & 38.1 & 11.2 & 6.4 & 3.3 & 33.9 & 10.0 & 114.7 & 74.4 & 19.1 \\
\hline 3.571 & 33.8 & 2.7 & 38.5 & 11.2 & 6.8 & 3.0 & 28.5 & 9.3 & 113.9 & 73.5 & 17.9 \\
\hline 4.166 & 33.3 & 2.7 & 37.4 & 11.4 & 6.7 & 3.0 & 31.4 & 9.5 & 115.5 & 75.1 & 19.4 \\
\hline CV (\%) & 5.0 & 6.5 & 5.0 & 5.4 & 9.5 & 6.4 & 29.1 & 20.4 & 11.6 & 20.2 & 15.5 \\
\hline
\end{tabular}


A.

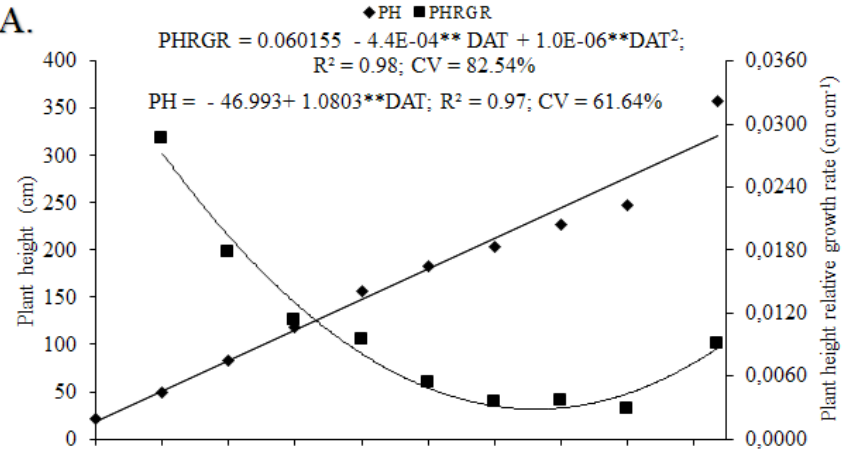

C.

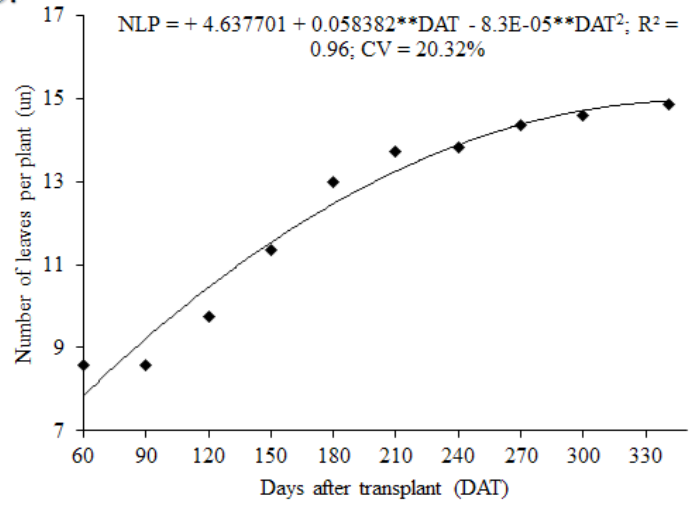

B.

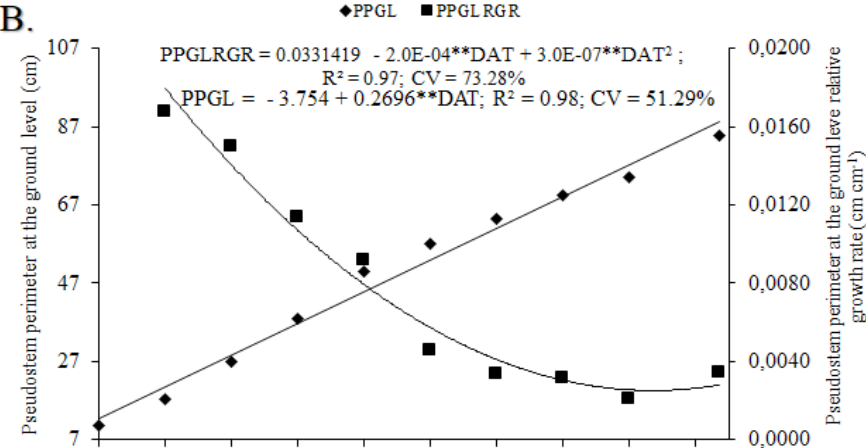

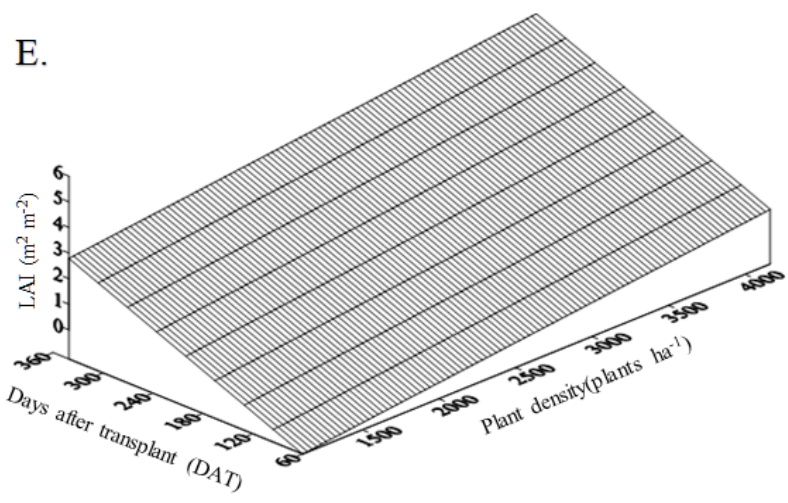

D.

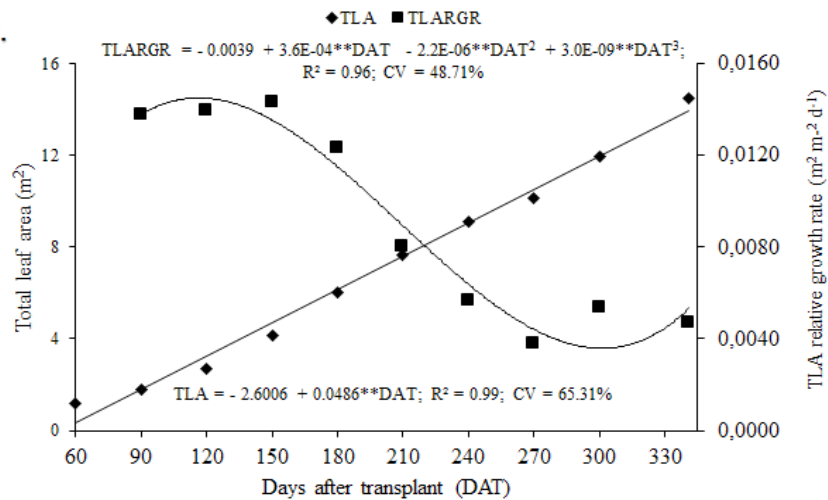

$\mathrm{LAI}=-2.749552+0.0139694 * \mathrm{DAT}+0.000697554 * \mathrm{PD} ; \mathrm{R}^{2}=0.9 ; \mathrm{CV}=65.21 \%$

** - Significant at $\mathrm{p} \leq 0.01$ by $\mathrm{t}$ test

Figure 1. Growth of plantain plants of the cultivar D'Angola under different plant densities as a function of days after transplanting (DAT)

found that 'D'Angola' plantain plants stand out with a mean of 14 leaves per plant at flowering, as confirmed by the data of the present study.

The plant density had no effect on the total leaf area (TLA) of 'D'Angola' plantain plants; the means of the treatments increased linearly as a function of DAT (Figure 1D). The mean TLA varied from $1.18 \mathrm{~m}^{2}$ (60 DAT) to $14.49 \mathrm{~m}^{2}$ (341 DAT). The estimated model showed an increase in TLA of $0.0486 \mathrm{~m}^{2}$ for each DAT.

Regarding the relative growth rate (RGR), $\mathrm{PH}_{\mathrm{RGR}}$ and $\mathrm{PPGL}_{\mathrm{RGR}}$ data fitted to an inverse quadratic model as a function of DAT, while TLA $_{\mathrm{RGR}}$ fitted to a cubic model (Figures 1A, B and D). The higher $\mathrm{PH}_{\mathrm{RGR}}$ and $\mathrm{PPGL}_{\mathrm{RGR}}$ were found at $90 \mathrm{DAT}$, and the lowest at 300 DAT; there was a slight increase in the RGR after 300 DAT up to 341 DAT, which is a similar result to that of TLA $A_{R G R}$.

Despite the linear increases in PH, PPGL, and TLA, in absolute values, the RGR presented different results, which was expected, since the RGR shows increases in PH, PPGL, and TLA expressed in units per DAT. This lower gain in these characteristics as a function of DAT is due to increases in shading caused by increases in leaf area index, which reduces the net assimilation rate (net photosynthetic rate minus the respiration and the photorespiration), which is essential to increase these plant attributes (Taiz et al., 2017).

The leaf area index (LAI) of the 'D'Angola' plantain plants increased linearly as the plant density and DAT were increased, showing a response surface (Figure 1E). The response surface estimated LAIs at 341 DAT of $2.79 ; 3.76 ; 3.95 ; 4.19 ; 4.50$; and 4.92 for populations of 1,$111 ; 2,500 ; 2,777 ; 3,125$; and 4,166 plants ha $^{-1}$, respectively.

Photosynthetically active radiation absorption is higher in denser crops due to their higher LAI (Turner et al., 2007), which increases chlorophyll concentrations. However, the radiation on the plant base decreases, consequently decreasing the development of suckers (Israeli, 1995). 
According to Turner et al. (2007), the LAI of plantain varies from 2 to 5, and a plantain crop with LAI near 4.5, as found for the populations equal to or higher than 3.125 plants $\mathrm{ha}^{-1}$, intercepts approximately $90 \%$ of the radiation; and increasing the LAI to values above 4.5 has little benefit to the crop, since most radiation is already intercepted.

The higher the LAI, the lower the cost with weed control, because the shading will be fast, decreasing weed emergence and maintaining a more favorable microclimate under the canopy of the crop.

The bunch (Figure 2A) and hand (Figure 2B) weights, water use efficiency for bunches (Figure 2C) and hands (Figure 2D), and number of hands (Figure 2E) of 'D'Angola' plantain plants as a function of plant density fitted to quadratic models.

The estimates of the models showed a maximum bunch weight yield of $19.35 \mathrm{Mg} \mathrm{ha}^{-1} \mathrm{cycle}^{-1}$ for plant density of 3,392 plants ha- ${ }^{-1}$ maximum hand weight yield of $15.47 \mathrm{Mg} \mathrm{ha}^{-1} \mathrm{cycle}^{-1}$

A.

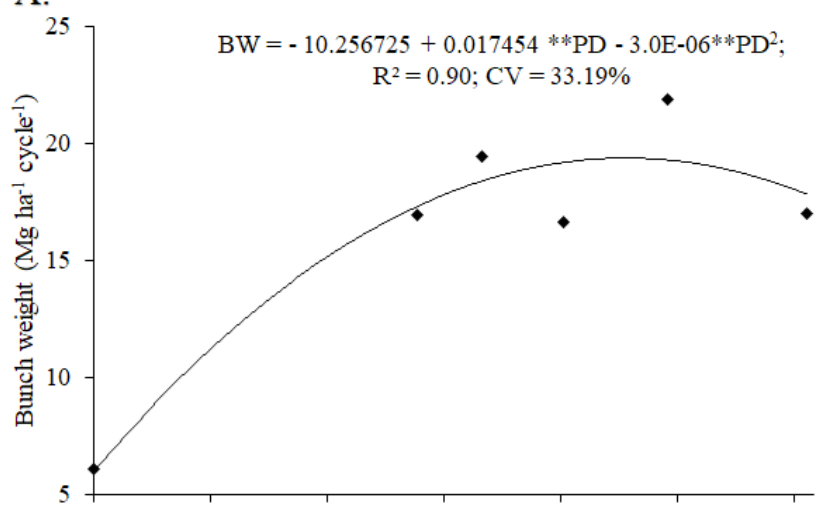

C.

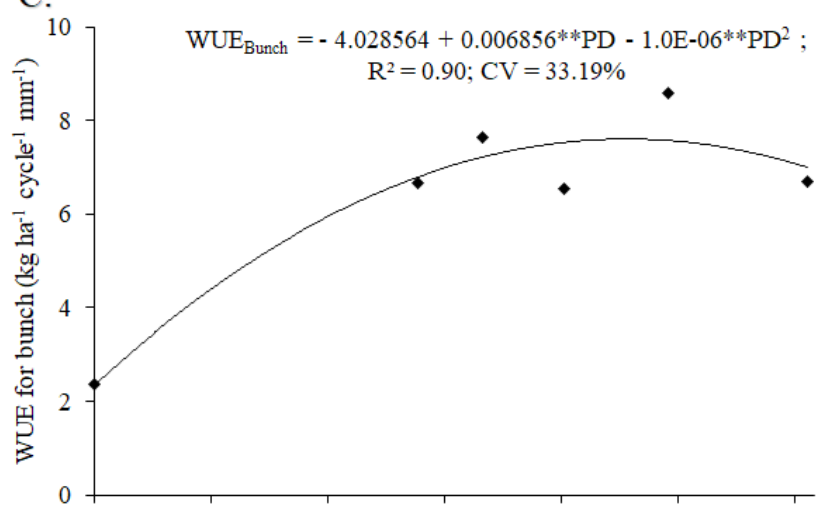

E.

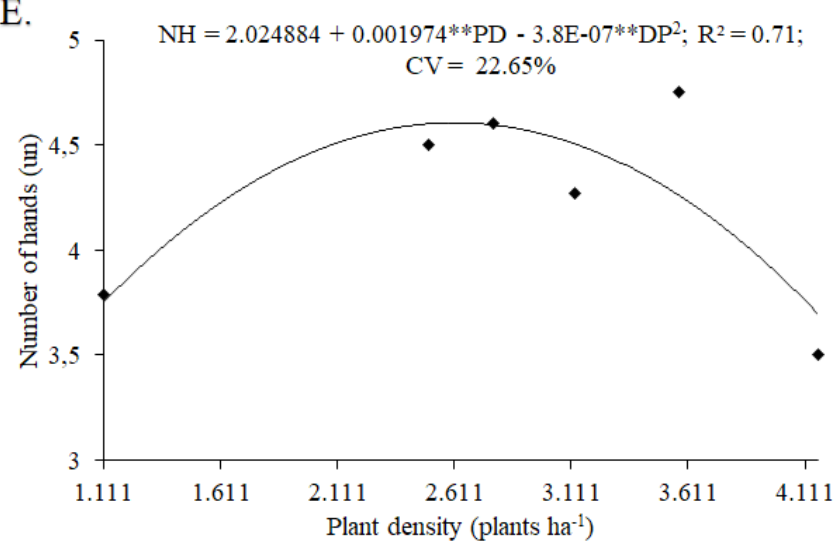

for 3,301 plants $\mathrm{ha}^{-1}$; and maximum number of hands of 4.61 for 2,614 plants ha-1.

The hand weight yield for plant density of 2,000 plants ha-1 was $12.06 \mathrm{Mg} \mathrm{ha}^{-1}$, which was a similar result to that found by Coelho et al. (2013), who reported 11.9 $\mathrm{Mg} \mathrm{ha}^{-1}$ for the same plant density.

The higher water use efficiencies found were $7.6 \mathrm{~kg} \mathrm{ha}^{-1}$ cycle $^{-1} \mathrm{~mm}^{-1}$ with plant density of 3,392 plants ha ${ }^{-1}$ for bunch weight yield (Figure 2D), $6.07 \mathrm{~kg} \mathrm{ha}^{-1} \mathrm{cycle}^{-1} \mathrm{~mm}^{-1}$ with 3,301 plants ha ${ }^{-1}$ for hand weight yield (Figure $2 \mathrm{E}$ ).

The other variables evaluated at harvest - hand weight, number of hands, number of fruits, fruit external length, fruit diameter, fruit mean weight, number of days for harvest, number of days for flowering, and flowering to harvest period - as a function of plant densities did not fit to any model. The means found were $4.86 \mathrm{~kg}$ for hand weight, 4.23 for number of hands, 23.87 for number of fruits, $23.69 \mathrm{~cm}$ for fruit external

B.

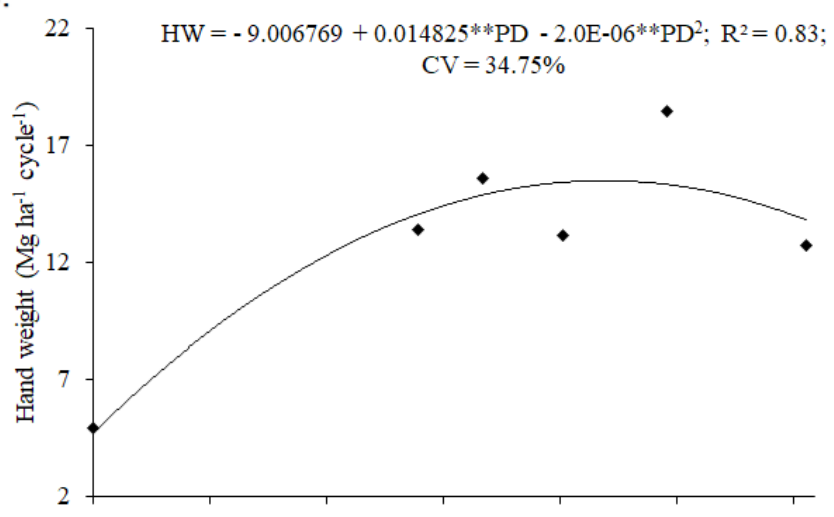

D.

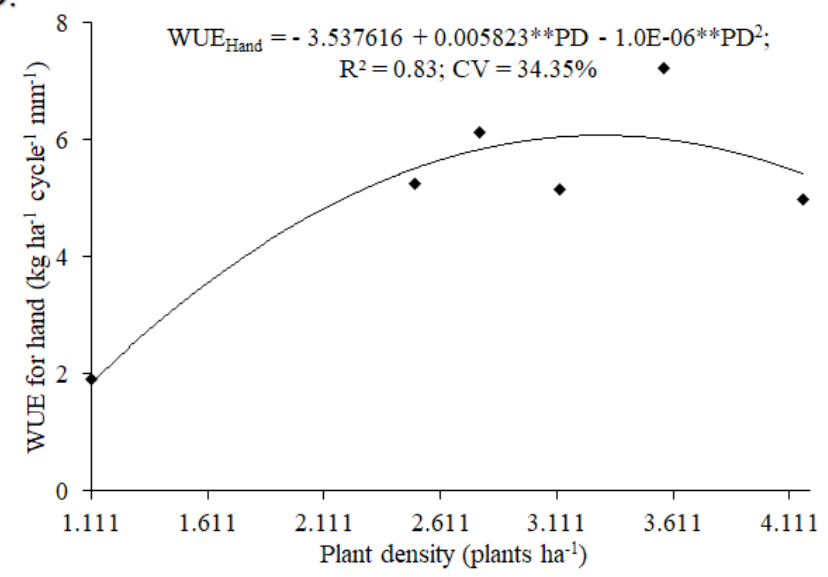

** - Significant at $\mathrm{p} \leq 0.01$ by t test

Figure 2. Fruit yield and water use efficiency of plantain plants D’Angola cultivar as a function of plant densities 
length, $40.44 \mathrm{~mm}$ for fruit diameter, $256.64 \mathrm{~g}$ for fruit mean weight, 379.19 for number of days for harvest, 305.41 for number of days for flowering, and 73.78 for number of days from flowering to harvest. These results were lower than those found by Faria et al. (2010) in the same experimental site for a population of 1,111 plants $\mathrm{ha}^{-1}$.

Hand weight and number of hands are the main interests to the producer, since they are the unities used for marketing (Silva et al., 2006). However, hand weight yield represents the net fruit yield of the unit for marketing and should be used to define the better plant density, provided that the fruit diameter and length in the density chosen assure a suitable fruit for marketing.

The highest net fruit yield was found for the plant density of 3,301 plants ha $^{-1}$, i.e., an planting spacing of $1.51 \times 2.0 \mathrm{~m}$, which resulted in a LAI of 4.32 at $341 \mathrm{DAT}$, which is a similar value to that recommended (4.5) by Turner et al. (2007) for a solar radiation interception of $90 \%$ by the plant canopy. This denotes the feasibility of the spacing of $1.5 \times 2.0 \mathrm{~m}$, i.e., a population of 3,333 plants ha-1 ${ }^{-1}$ to obtain a LAI of 4.34 , which was confirmed by the maintenance of the fruit class for marketing, regardless of the plant density.

The gas exchanges of the 'D'Angola' plantain fitted to an increasing linear model as a function of plant density and reading time for leaf temperature (Figure 3 ). The leaf temperature increased $0.001{ }^{\circ} \mathrm{C}$ when measured at $8: 00 \mathrm{~h}$, and $0.0007^{\circ} \mathrm{C}$ when measured at $14: 00 \mathrm{~h}$, for each increase of plant in the population.

According to Donato et al. (2015), increasing plant density is a technic that improves thermal comfort for banana plants; however, the leaf temperature of 'D'Angola' plantain increased as the plant density was increased. The increase in plant density decreases the exchanges of sensible heat within the plantain crop, because it decreases the air movement and removes the bordering

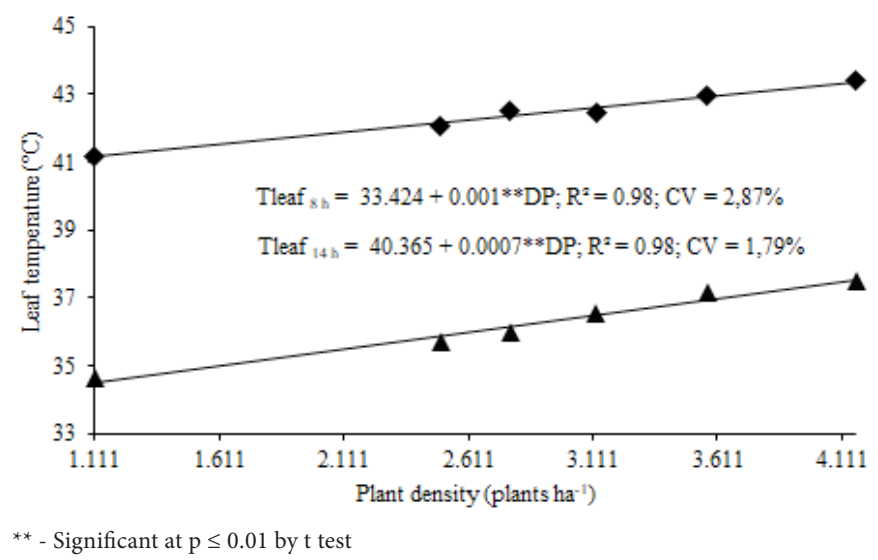

Figure 3. Leaf temperature $\left(\mathrm{T}_{\text {leaf }}\right)$ measured at 8:00 h and 14:00 $\mathrm{h}$ on the third leaf of plantain plants D'Angola cultivar grown under different plant densities air layer on the leaf, probably increasing leaf temperature in plants grown under high plant density. However, the thermal comfort in the interior of the canopy probably increases as the plant density is increased, because the leaf temperature is measured on the third leaf at the top of the canopy.

Photosynthesis rates, transpiration, stomatal conductance, solar radiation incidence on the leaf, substomatal $\mathrm{CO}_{2}$ concentration, carboxylation efficiency, instantaneous water use efficiency, and quantum efficiency of photosynthesis varied between reading times (Table 3 ). The photosynthetically active radiation incidence on the leaf $\left(Q_{\text {leaf }}\right)$ and internal $\mathrm{CO}_{2}$ concentration $(\mathrm{Ci})$ were similar in both reading times. The $Q_{\text {leaf }}$ found were within the range that provides the maximum photosynthesis rates - 1,500 to $2,000 \mu \mathrm{mol}$ photons $\mathrm{m}^{-2} \mathrm{~s}^{-1}$ (Turner et al. 2007).

The photosynthesis was higher at 8:00 h, and transpiration was higher at 14:00 h (Table 3), as also found by Arantes et al. (2016) for banana. The increase in temperature combined with a low air relative humidity - a high atmosphere vapor pressure deficit, which is common for the local semiarid conditions, mainly in September, October and February (Donato et al., 2015) - increases the evapotranspiration demand and affects all metabolic and physiological processes of the plant.

The higher leaf temperature $\left(\mathrm{T}_{\text {leaf }}\right)$ at 14:00 h (Figure 3) affected the photosynthesis (A) by compromising the functioning of the enzymatic system, which causes stomatal closure by limiting the entry of $\mathrm{CO}_{2}$. Despite the lower stomatal conductance (gs), the transpiration (E) was higher at 14:00 h; and the instantaneous water use efficiency $(\mathrm{A} / \mathrm{E})$, photosynthesis photochemical efficiency $\left(\mathrm{A} / \mathrm{Q}_{\text {leaf }}\right)$, and carboxylation efficiency $(\mathrm{A} / \mathrm{Ci})$ were lower at 14:00 h, indicating an increase in the rubisco activity for oxygenase in detriment of carboxylation, when compared to those found in the 8:00 h readings (Donato et al., 2015; Arantes et al., 2016).

The optimum temperature for $\mathrm{CO}_{2}$ carboxylation in plants with $\mathrm{C} 3$ photosynthetic mechanism, such as plantain, is approximately $22^{\circ} \mathrm{C}$, whereas for growth and development it is approximately $27^{\circ} \mathrm{C}$ (Robinson \& Galán Saúco, 2012). The leaf temperature in 'D'Angola' plantain varied from 34 to $36^{\circ} \mathrm{C}$ at $8: 00 \mathrm{~h}$, and from 41 to $43^{\circ} \mathrm{C}$ at $14: 00 \mathrm{~h}$, as a function of plant densities (Figure 3), which were above of the optimum temperature for photosynthesis.

Carboxylase and oxygenase activities of rubisco are balanced by its kinetics, temperature, and $\mathrm{CO}_{2}$ and $\mathrm{O}_{2}$ substrate concentration. Under normal $\mathrm{CO}_{2}$ concentrations, increases in temperature change the kinetic constants of the rubisco and increase the oxygenation rate preferentially to carboxylation, consequently increasing photorespiration and decreasing net photosynthesis (Taiz et al., 2017), as also found by Arantes et al. $(2016 ; 2018)$.

Table 3. Physiological variables measured at 8:00 $\mathrm{h}$ and 14:00 $\mathrm{h}$ on the third leaf of 'D'Angola' plantain subjected to different plant densities

\begin{tabular}{ccccccccccc}
\hline RT & $\mathbf{Q}_{\text {leaf }}$ & $\mathbf{C}_{\mathrm{i}}$ & $\mathbf{E}$ & gs & $\mathbf{A}$ & $\mathbf{A} / \mathbf{E}$ & $\mathbf{A} / \mathbf{C}_{\mathrm{i}}$ & $\mathbf{A} / \mathbf{Q}_{\text {leal }}$ & $\mathbf{V P D}$ \\
\hline 8 & $1506.49 \mathrm{a}$ & $220.38 \mathrm{a}$ & $6.89 \mathrm{~b}$ & $0.47 \mathrm{a}$ & $22.37 \mathrm{a}$ & $3.30 \mathrm{a}$ & $0.10 \mathrm{a}$ & $0.016 \mathrm{a}$ & $0.8 \mathrm{~b}$ \\
14 & $1595.43 \mathrm{a}$ & $226.42 \mathrm{a}$ & $9.34 \mathrm{a}$ & $0.34 \mathrm{~b}$ & $14.30 \mathrm{~b}$ & $2.11 \mathrm{~b}$ & $0.06 \mathrm{~b}$ & $0.010 \mathrm{~b}$ & $1.5 \mathrm{a}$ \\
CV $(\%)$ & 20.72 & 12.64 & 33.53 & 63.69 & 31.08 & 45.57 & 33.1 & 49.92 & 31.1 \\
\hline
\end{tabular}

RT - Readig time (hours); $\mathrm{Q}_{\text {Leaf }}\left(\mu \mathrm{mol}\right.$ fótons $\left.\mathrm{m}^{-2} \mathrm{~s}^{-1}\right)$ - photosynthetically active solar radiation on the leaf; $\mathrm{C}_{\mathrm{i}}\left(\mu \mathrm{mol} \mathrm{CO}_{2} \mathrm{~mol}^{-1}\right)$ - internal CO${ }_{2} \mathrm{concentration} \mathrm{E}\left(\mathrm{mmol} \mathrm{H}_{2} \mathrm{O}^{-2} \mathrm{~s}^{-1}\right)$ - transpiration rate; $\mathrm{g}_{\mathrm{s}}\left(\mathrm{mol} \mathrm{H}_{2} \mathrm{O} \mathrm{m}^{-2} \mathrm{~s}^{-1}\right)$ - stomatal conductance; $\mathrm{A}\left(\mu \mathrm{mol} \mathrm{CO} \mathrm{m}^{-2} \mathrm{~s}^{-1}\right)$ - photosynthesis rate; $\mathrm{A} / \mathrm{C}_{\mathrm{i}}-\mathrm{CO}_{2}$ carboxylation efficiency $\left(\mu \mathrm{mol} \mathrm{CO}_{2} \mathrm{~m}^{-2} \mathrm{~s}^{-1} / \mu \mathrm{mol} \mathrm{CO}_{2} \mathrm{~mol}^{-1}\right)$; $\mathrm{A} / \mathrm{E}\left(\mu \mathrm{mol} \mathrm{CO} \mathrm{m}^{-2} \mathrm{~s}^{-1} / \mathrm{mmol} \mathrm{H}_{2} \mathrm{O} \mathrm{m}^{-2} \mathrm{~s}^{-1}\right)$ - instantaneous water use efficiency; $\mathrm{A} / \mathrm{Q}_{\text {leaf }}$ - photosynthesis photochemical efficiency; VPD - vapor pressure deficit ( $\mathrm{kPa}$ ); Means followed by the same letter in the columns are not different by the F test at $\mathrm{p} \leq 0.05$ 
The highest photochemical efficiency was found at 8:00 h. The quantum yield of photosynthesis in C3 plants is high up to approximately $30^{\circ} \mathrm{C}$, and it decreases in banana under temperatures above $34^{\circ} \mathrm{C}$ (Robinson \& Galán Saúco, 2012), explaining the lower quantum efficiency at 14:00 h because of the higher leaf temperatures observed in this reading time (Arantes et al., 2016; 2018).

\section{Conclusions}

1. The nutritional status of 'D'Angola' plantain is not dependent on plant density.

2. Variations in plant height, pseudostem perimeter at the ground level, number of functional leaves, and total leaf area of 'D'Angola' plantain are not dependent on the plant density, whereas the leaf area index increases as the plant density is increased.

3. Leaf temperature of 'D'Angola' plantain increases as the plant density is increased, and is higher in the afternoon.

4. The maximum estimated fruit hand weight yield of the plantain was $15.45 \mathrm{Mg} \mathrm{ha}^{-1}$ cycle $^{-1}$ for a population of 3,386 plants $\mathrm{ha}^{-1}$, which provided a leaf area index of 4.38 ; whereas the highest estimated water use efficiency found was $6.07 \mathrm{~kg} \mathrm{ha}^{-1} \mathrm{cycle}^{-1} \mathrm{~mm}^{-1}$ for a plant density of 3,301 plants ha ${ }^{-1}$.

5. The use of 3,333 plants ha-1 with spacing of $1.5 \times 2.0 \mathrm{~m}$ is recommended for 'D'Angola' plantain crops.

\section{Literature Cited}

Arantes, A. de M.; Donato, S. L. R.; Silva, S. de O. e. Relação entre características morfológicas e componentes de produção em plátanos. Pesquisa Agropecuária Brasileira, v.45, p.224-227, 2010. https://doi.org/10.1590/S0100-204X2010000200015

Arantes, A. de M.; Donato, S. L. R.; Siqueira, D. L.; Coelho, E. F. Gas exchange in 'Pome' banana plants grown under different irrigation systems. Engenharia Agrícola, v.38, p.197-207, 2018. https://doi. org/10.1590/1809-4430-eng.agric.v38n2p197-207/2018

Arantes, A. de M.; Donato, S. L. R.; Siqueira, D. L.; Coelho, E. F.; Silva, T. S. Gas exchange in different varieties of banana prata in semiarid environment. Revista Brasileira de Fruticultura, v.38, p.1-12, 2016. https://doi.org/10.1590/0100-29452016600

Barrera, J.; Cayón, G.; Robles, J. Influencia de la exposición de las hojas y el epicarpio de frutos sobre el desarrollo y la calidad del racimo de plátano Hartón (Musa AAB Simmonds). Agronomía Colombiana, v.27, p.73-79, 2009.

Borges, A. L.; Albuquerque, A. F. A.; Coelho, E. F.; Lima, M. B.; Donato, S. L. R.; Rodriguez, M. A. D.; Silva, S. O. E.; Cordeiro, Z. J. M. Sistema de produção: Cultivo de plátanos (Bananeiras tipo Terra). Cruz das Almas: Embrapa Mandioca e Fruticultura, 2016 (Sistema de Produção - Versão Eletrônica). Available on: <https:// www.spo.cnptia.embrapa.br/conteudo?p_p_id=conteudoportlet_ WAR_sistemasdeproducaolf6_1ga1ceportlet $\&$ p_p_ lifecycle $=0 \& p \_p \_s t a t e=$ normal\&p_p_mode $=$ view $\&$ p_p col_id=column-1\&p_p_col_count $=1 \&$ p_r_p_-76293187_ sistemaProducaoId=8701\&p_r_p_-996514994_topicoId=10001> Accessed on: Nov.2016.

Cavalcante, M. de J. B.; Andrade Neto, R. de C.; Ledo, A. da S.; Gondim, T. M. de S.; Cordeiro, Z. J. M. Manejo fitotécnico da bananeira, cultivar D'Angola (AAB), visando ao controle da Sigatoka-negra. Revista Caatinga, v.27, p.201-208, 2014.
Coelho, E. F.; Donato, S. L. R.; Oliveira, P. M. de; Cruz, A. J. S. Relações hídricas II: Evapotranspiração e coeficiente de cultura. In: Coelho, E. F. (ed). Irrigação da bananeira. Cruz das Almas: Embrapa Mandioca e Fruticultura, 2012. Cap 2. p.87-117.

Coelho, E. F.; Oliveira, R. C. de; Pamponet, A. J. M. Necessidades hídricas de bananeira tipo Terra em condições de tabuleiros costeiros. Pesquisa Agropecuária Brasileira, v.48, p.1260-1268, 2013. https://doi.org/10.1590/S0100-204X2013000900010

Donato, S. L. R.; Coelho, E. F.; Santos, M. R. dos; Arantes, A. M.; Rodrigues, M. G. V. Eficiência de uso da água em bananeira. Informe Agropecuário, v.36, p.46-59, 2015.

Faria, H. C. de; Donato, S. L. R.; Pereira, M. C. T.; Silva, S. de O. E. Avaliação fitotecnica de bananeiras tipo Terra sob irrigação em condições semiáridas. Ciência e Agrotecnologia, v.34, p.830-836, 2010. https://doi.org/10.1590/S1413-70542010000400006

Israeli, Y.; Plaut, Z.; Schwartz, A. Effect of shade on banana morphology, growth and production. Scientia Horticulturae, v. 62, p. 45-56, 1995. https://doi.org/10.1016/0304-4238(95)00763-J

Robinson, J. C.; Galán Saúco, V. Plátanos y bananas. 2.ed. Madrid: Mundi-Prensa, 2012.321p.

Rodrigues, M. G. V.; Dias, M. S. C.; Pacheco, D. D. Influência de diferentes níveis de desfolha na produção e qualidade dos frutos da bananeira "Prata-Anã". Revista Brasileira de Fruticultura, v.31, p.755-762, 2009. https://doi.org/10.1590/S0100-29452009000300019

Rodrigues, M. G. V.; Pacheco, D. D.; Natale, W.; Silva, J.T. da. Amostragem foliar da bananeira 'Prata-Anã'. Revista Brasileira de Fruticultura, v.32, p.321-325, 2010. https://doi.org/10.1590/S010029452010005000039

Rodríguez González, C.; Cayón Salinas, D. G.; Mira Castillo, J. J. Efecto del número de hojas funcionales a la floración sobre la producción de banano Gran Enano (Musa AAA Simmonds). Revista da Faculdad Nacional de Agronomia de Medellin, v.65, p.6585-6591, 2012.

Rosales, F. E.; Alvarez, J. M. Vargas, A.; Guia prática para La producción de plátano con altas densidades - Experiencias de América Latina y el Caribe. In: Rosales, F. E. (Ed). Montepellier: Bioversity Internacional. 2008. 24p.

Santos, M. R. dos; Donato, S. L. R.; Magalhães, D. B.; Cotrim, M. P. Precocity, yield and water-use efficiency of banana plants under planting densities and irrigation depths, in semiarid region. Pesquisa Agropecuária Tropical, v. 49, p. e53036, 2019. https://doi.org/10.1590/1983-40632019v4953036

Silva, J. T. A. da; Borges, A. L.; Dias, M. S. C.; Costa, E. L. da; Prudêncio, J. M. Diagnóstico nutricional da bananeira 'Prata Anã para o Norte de Minas Gerais. Belo Horizonte: EPAMIG, 2002.16p. Boletim Técnico, 70

Silva, S. de O. e; Pires, E. T.; Pestana, R. K. N.; Alves, J. da S.; Silveira, D. de C. Avaliação de clones de banana cavendish. Ciência e Agrotecnologia, v.30, p.832-837, 2006. https://doi.org/10.1590/ S1413-70542006000500002

Taiz, L.; Zeiger, E.; Møller, I. M.; Murphy, A. Fisiologia e desenvolvimento vegetal. 6.ed. Porto Alegre: Artmed, 2017. 858p.

Turner, D. W.; Fortescue, J. A.; Thomas, D. S. Environmental physiology of the bananas (Musa spp.). Brazilian Journal of Plant Physiology, v.19, p.463-484, 2007. https://doi.org/10.1590/S167704202007000400013

Zucoloto, M.; Lima, J. S. de S.; Coelho, R. I. Modelo matemático para estimativa da área foliar total de bananeira Prata-Anã. Revista Brasileira de Fruticultura, v.30, p.1152-1154, 2008. https:/doi. org/10.1590/S0100-29452008000400050 